Canadian

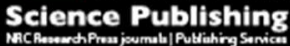

Canadian Journal of Zoology Revue canadienne de zoologie

\title{
Variation in the intensity and prevalence of macroparasites in migratory caribou: a quasi-circumpolar study
}

\begin{tabular}{|c|c|}
\hline Journal: & Canadian Journal of Zoology \\
\hline Manuscript ID & cjz-2015-0190.R2 \\
\hline Manuscript Type: & Article \\
\hline Date Submitted by the Author: & 21-Mar-2016 \\
\hline Complete List of Authors: & $\begin{array}{l}\text { Simard, Alice-Anne; Université Laval, Département de biologie et Centre } \\
\text { d'études nordiques } \\
\text { Kutz, Susan; University of Calgary } \\
\text { Ducrocq, Julie; Calgary University, Faculty of Veterinary Medicine } \\
\text { Beckmen, Kimberlee; Alaska Department of Fish and Game, Division of } \\
\text { Wildlife Conservation } \\
\text { Brodeur, Vincent; Ministère des Forêts, de la Faune et des Parcs, Direction } \\
\text { de la gestion de la faune du Nord-du-Québec } \\
\text { Campbell, Mitch; Government of Nunavut, Department of Environment } \\
\text { Croft, Bruno; Government of the Northwest Territories, Environment and } \\
\text { Natural Resources } \\
\text { Cuyler, Christine; Greenland Institute of Natural Resources, } \\
\text { Davison, Tracy; Government of the Northwest Territories in Inuvik, } \\
\text { Department of ENR } \\
\text { Elkin, Brett; Government of the Northwest Territories, Environment and } \\
\text { Natural Resources } \\
\text { Giroux, Tina; Athabasca Denesuline Né Né Land Corporation } \\
\text { Kelly, Allicia; Government of the Northwest Territories, Environment and } \\
\text { Natural Resources } \\
\text { Russell, Don; Environnement Canada } \\
\text { Taillon, Joëlle; Université Laval, Département de biologie et Centre } \\
\text { d'études nordiques } \\
\text { Veitch, Alasdair; Government of the Northwest Territories, Environment } \\
\text { and Natural Resources } \\
\text { Côté, Steeve D.; Université Laval, Département de Biologie and Centre of } \\
\text { Northern Studies }\end{array}$ \\
\hline Keyword: & $\begin{array}{l}\text { COMPARATIVE < Discipline, parasite, caribou, Rangifer tarandus, helminth, } \\
\text { arthropod, monitoring }\end{array}$ \\
\hline
\end{tabular}




\section{Variation in the intensity and prevalence of macroparasites in migratory caribou: a quasi-circumpolar study}

Alice-Anne Simard, Susan Kutz, Julie Ducrocq, Kimberlee Beckmen, Vincent Brodeur, Mitch Campbell, Bruno Croft, Christine Cuyler, Tracy Davison, Brett Elkin, Tina Giroux, Allicia Kelly, Don Russell, Joëlle Taillon, Alasdair Veitch, Steeve D. Côté

A.-A.S, J.T., S.D.C. Université Laval, Département de biologie and Centre d'études nordiques, Pavillon Alexandre-Vachon, 1045 avenue de la Médecine, Québec, Québec, Canada, G1V 0A6

S.K., J.D. University of Calgary, Faculty of Veterinary Medicine, 3330 University Drive NW, Calgary, Alberta, Canada, T2N 4N1

K.B. Alaska Department of Fish and Game, Division of Wildlife Conservation, 1300 College Road, Fairbanks, Alaska, USA, 99701

V.B. Ministère des Forêts, de la Faune et des Parcs, Direction des opérations régionales du Norddu-Québec, 951 boul. Hamel, Chibougamau, Québec, Canada, G8P 2 Z3

M.C. Government of Nunavut, Department of Environment, Kivalliq Region. P.O. Box 120, Arviat, Nunavut, Canada, X0C 0E0

B.C., B.E. Government of the Northwest Territories, Environment and Natural Resources, Wildlife Division, $6005102-50^{\text {th }}$ Ave, Yellowknife, Northwest Territories, Canada, X1A 3S8

C.C. Greenland Institute of Natural Resources, P. O. Box 570, 3900 Nuuk, Greenland 
T.D. Government of the Northwest Territories in Inuvik, Department of ENR, Inuvik Region Shell Lake, P. O. Box 2749, Inuvik, Northwest Territories, Canada, X0E 0T0

T.G. Athabasca Denesuline Né Né Land Corporation, P.O. Box 23126, South Hill, Prince Albert, Saskatchewan, Canada, S6V 8A7

A.K. Government of the Northwest Territories, Environment and Natural Resources, South Slave Region, P.O. Box 900, Fort Smith, Northwest Territories, Canada, X0E 0P0

D.R. Conservation and Sustainability, Environment Canada, Canadian Wildlife Service, Pacific and Yukon Region, 91782 Alaska Hwy, Whitehorse, Yukon, Canada, Y1A 5B7

A.V. Government of the Northwest Territories, Environment and Natural Resources, Wildlife Management - Sahtu Region, P.O. Box 130, Norman Wells NT, Canada, X0E 0V0

\section{Corresponding author:}

Alice-Anne Simard

Université Laval, Département de biologie and Centre d'études nordiques, Pavillon AlexandreVachon, 1045 avenue de la Médecine, Québec, Québec, Canada, G1V 0A6

Phone number : (418) 803-4992

Fax number : (418) 656-2043

alice-anne.simard.1@ulaval.ca 


\begin{abstract}
Comparative studies across time and geographical regions are useful to improve our understanding of the health of wildlife populations. Our goal was to study parasitism in migratory caribou (Rangifer tarandus L., 1758) of North America and Greenland. A total of 1507 caribou were sampled across twelve herds to assess seven of their main helminth and arthropod macroparasites between 1978 and 2010. We sought to determine which factors such as sex, age class, herd size, and season best explained the prevalence and intensity of those parasites. Intensity of Hypoderma tarandi (L., 1758) increased with age for males while the opposite was observed in females. Prevalence of Fascioloides magna (Bassi, 1875), Taenia hydatigena (Pallas, 1766), and Cephenemyia trompe (Modeer, 1786) was higher in adults than in calves. Prevalence of F. magna and T. hydatigena were higher at high herd size than at lower herd size. Greenland herds had the lowest prevalence of T. hydatigena and Taenia krabbei (Moniez, 1879), a higher intensity of $H$. tarandi and a higher prevalence of $C$. trompe than the other herds. Of the herds from Québec and Labrador, the Rivière-George herd had a higher prevalence of $F$. magna than the Rivière-aux-Feuilles herd. Our research provides the first comparative survey of these parasites of caribou across a broad spatial-temporal range.
\end{abstract}

Keywords: comparative, parasite, caribou, Rangifer tarandus, helminth, arthropod, monitoring 


\section{Résumé}

Les études comparatives réalisées avec un large éventail spatio-temporel sont fort utiles pour améliorer notre compréhension de l'état de santé des populations d'animaux sauvages. Nous avons étudié le parasitisme chez le caribou migrateur (Rangifer tarandus L., 1758) en Amérique du Nord et au Groenland. Un total de 1507 caribous ont été échantillonnés à travers douze troupeaux pour sept de leurs principaux helminthes et arthropodes macroparasites entre 1978 et 2010. Nous avons tenté de déterminer quels facteurs tels que le sexe, la classe d'âge, la taille du troupeau et la saison expliquaient le mieux la prévalence et l'intensité de ces parasites. L'intensité de Hypoderma tarandi (L., 1758) augmentait avec l'âge chez les mâles alors que le contraire a été observé chez les femelles. Les prévalences de Fascioloides magna (Bassi, 1875), Taenia hydatigena (Pallas, 1766) et Cephenemyia trompe (Modeer, 1786) étaient plus élevées chez les adultes que chez les jeunes. Les prévalences de $F$. magna et de $T$. hydatigena étaient plus élevées à forte taille de troupeau qu'à faible taille de troupeau. Les troupeaux du Groenland avaient une plus grande intensité de $H$. tarandi et une plus grande prévalence de $C$. trompe que les autres troupeaux. Cette recherche fournit la première étude comparative de ces parasites à large échelle spatiale et géographique.

Mots-clés: comparative, parasite, caribou, Rangifer tarandus, helminthe, arthropode, suivi 


\section{Introduction}

Determining parasite biodiversity as well as the abundance and distribution of parasites within animal populations across a species range is crucial for understanding a population's health status and detecting changes (Scott 1988; Hoberg et al. 2003; Hoberg et al. 2008). Parasitism is a major driver of health status and many studies have shown that parasites influence the fitness of organisms and populations through their effects on individual life-history components (Anderson and May 1978; May and Anderson 1978; Gulland 1992; Hudson et al. 1998; Irvine et al. 2006). Host populations often show a strong variation in the prevalence - the percent of infected individuals in the host population - and in the intensity of infection - the average number of parasites per infected host. This variability is typical for macroparasites and is a function of a number of things, including the level of exposure and the ability to mount an immune reponse (Hudson et al. 2002; Christe et al. 2007).

Various factors can influence parasitism. Sex of the host can impact the intensity of infection, with males often bearing higher burdens than females (Hamilton and Zuk 1982; Zuk 1990; Poulin 1996), with some exceptions (McCurdy et al. 1998; Morales-Montor et al. 2004). Physiological, morphological, and behavioral differences between females and males could operate to create a sexual bias in infection levels. For instance, steroid hormones, particularly testosterone, could depress the immune system and thus play a major role in sex differences (Zuk 1990; Folstad and Karter 1992) and generate sex-specific seasonal patterns of parasite abundance. Age of the host can also influence parasitism as the prevalence of long-lived parasites generally increase with age, starting when an animal is first susceptible to infection (Hudson and Dobson 1995). Many mechanisms could be responsible for age-dependent parasitism levels such as mortality induced by parasite infection, acquired immunity, and changes in exposure to infection with age (Hudson 
and Dobson 1995; Wilson et al. 2001). Transmission rate is also thought to increase with density of the host (Arneberg et al. 1998) and host group size (Patterson and Ruckstuhl 2013) because the probability that the infectious stage of the parasite (e.g. eggs or larvae) encounters a host then increases (Côté and Poulin 1995).

Seasonality can also affect the activity and the rate of transmission of parasites. This is particularly true for vector borne pathogens and parasites that have life cycle stages that are free in the environment and whose development and/or survival are sensitive to climatic conditions (Harvell et al. 2002; Kutz et al. 2004; Kutz et al. 2009; Hoar et al. 2012). Because the rate of transmission of parasites is affected by climate, host-parasite systems could be greatly impacted by climate change (Kutz et al. 2005). In the Arctic, the effects of climate change are already evident, with mean surface temperature having increased two to three times more than for the rest of the planet in the past 150 years (Post et al. 2009; IPCC 2013). Predictions of a warmer and wetter Arctic are expected to alter host-parasite interactions by increasing transmission rates and transmission periods, by shifting temporal patterns of parasite life history and by expanding spatial range of some parasites by decreasing environmental constraints (Kutz et al. 2004; Kutz et al. 2005; Brooks and Hoberg 2007; Hoar et al. 2012). However, for some parasites the impacts of a warming arctic climate are not as clear, with extremes in heat negatively impacting transmission (Hoar et al. 2012; Molnár et al. 2013; Kutz et al. 2013b). Thus, arctic ecosystems can provide considerable insight to understand and predict the responses of host-parasite systems to warming on a global scale (Kutz et al. 2009; Davidson et al. 2011).

Caribou (Rangifer tarandus L., 1758) are widespread and abundant across the circumpolar Arctic (Festa-Bianchet et al. 2011). This is a keystone species supporting predator populations (Dale et al. 1994; Mowat and Heard 2006; Musiani et al. 2007), as well as affecting vegetation structure 
(Olofsson et al. 2009; Champagne et al. 2012; Zamin and Grogan 2013). Caribou are also central to the culture, spirituality, and diet of northern aboriginal peoples (Hummel and Ray 2008; FestaBianchet et al. 2011). Many caribou herds of the Arctic are now declining (Vors and Boyce 2009) and may not recover to herd sizes prior to the declines (Festa-Bianchet et al. 2011). The causes of the declines are unknown although habitat degradation, harvesting, industrial development and climate change could be singly or cumulatively responsible (Festa-Bianchet et al. 2011). Infectious diseases and parasites may also be a contributing driver for caribou herd fluctuations but empirical data supporting this assertion remain scarce (Albon et al. 2002). Here, we report variations in prevalence and intensity of infection of the main macroparasites of migratory caribou across several Arctic regions and years that will allow comparisons among herds and serve as baseline data against which to assess caribou vulnerability to parasitism and responses to environmental change. The objectives of this study were: i) to determine which combinations of factors such as sex, age class, herd size, and season best explained the prevalence and intensity of seven of the main macroparasites of caribou and ii) to compare the prevalence and intensity of these macroparasites among twelve herds distributed across North America and Greenland.

\section{Materials and methods}

A total of 1507 caribou (Table 1) were sampled across twelve herds from Alaska to Greenland (Figure 1) between 1978 and 2010 with the greatest sampling effort in 2007-2010. Sampling was done intensively in the Rivière-George and Rivière-aux-Feuilles herds since 1978 while it was done sporadically in 1994 in the Beverly/Ahiak and Cape Bathurst herds, in 1997 and 1998 in the Bluenose East herd, and in 2000 in the Beverly/Ahiak herd. In addition, most herds were sampled intensively during the International Polar Year initiative (2007-2010), when the CircumArctic Rangifer Monitoring and Assessment Network (CARMA; www.caff.is/carma) (Russell et al. 
2013) coordinated widespread sampling of migratory caribou and reindeer herds across the Arctic. Standardized sampling protocols were applied to establish baseline data on the diversity and abundance of pathogens and parasites (Kutz et al. 2013a). Animal capture and culling were done in accordance with guidelines from the Canadian Council on Animal Care. The following sampling periods were defined considering the ecology of caribou and the studied parasites: winter (December to mid-February), late winter/early spring (mid-February to April), spring migration/calving grounds (May to July), late summer (August and September), and fall migration (October and November) (Sharma et al. 2009). For H. tarandi and C. trompe (see below), we used only data collected in late winter because it is the only period of the year when larvae are clearly visible by gross examination (Nilssen and Haugerud 1994). For all other parasites, prevalence and intensity were established for all seasons when data were collected. Because different techniques to assess age were used for different herds, we used age classes as attributed in the field instead of exact age. Age criteria were as follows: calves (less than 12 months), yearlings (between 12 and 23 months) and adults (24 months and older). We used data collected from aerial surveys to divide herd sizes in five classes that could be compared across herds and accounted for both herd size and trend: low and increasing, high and increasing, around the peak, high and decreasing, and low and decreasing (Pachkowski et al. 2013).

\section{Studied species}

We studied seven of the main macroparasites of caribou: warble larvae (Hypoderma tarandi L., 1758), nose bot larvae (Cephenemyia trompe Modeer, 1786), liver cysts (Taenia hydatigena Pallas, 1766), giant liver flukes (Fascioloides magna Bassi, 1875), hydatid cysts (Echinococcus canadensis Batsch, 1786), lungworms (Dictyocaulus eckerti Skrjabin, 1931), and muscle cysts (Taenia krabbei Moniez, 1879) (Table 2). The lungworms reported here have not been 
molecularly identified, but are likely D. eckerti based on the literature (Höglund et al. 2003; Kutz et al. 2012). By default, all cysts in caribou muscles have previously been described as $T$. krabbei, but Catalano et al. (2014) have recently underlined the potential for misidentification in previous studies because $T$. krabbei and Taenia arctos are morphologically very similar, especially in their immature form (Haukisalmi et al. 2011). Taenia arctos has been reported in muskoxen (Ovibos moschatus Zimmermann, 1780) in Greenland and in other species in North America but not in Rangifer (Haukisalmi et al. 2011; Lavikainen et al. 2011; Raundrup et al. 2012; Catalano et al. 2014). The muscle cysts reported here have not been molecularly identified, but are likely T. krabbei (S. Kutz, unpubl. data). Data were collected only by scientists and trained personnel to limit biases associated with harvest by hunting. For E. canadensis and $D$. eckerti, total count of cysts and worms were done on the whole surface of the lungs and in the lungs after dissecting them along the bronchi and major bronchioles. For $H$. tarandi, total count of larvae was done on the underside of the skin of the top and the sides of the back. For $C$. trompe, total count of nose bot larvae was done in the whole pharynx once the head was removed. For F. magna and T. hydatigena, total count of flukes and cysts was done in the liver after cutting it into $1 \mathrm{~cm}$ slices (the mesentery and omentum were not systematically examined for T. hydatigena thus only liver counts were used). For T. krabbei, total count of cysts was done in both the heart and the gastrocnemius muscle after making transverse cuts through them (Kutz et al. 2013a). Fascioloides magna is known to occur only in the Québec and Labrador herds (Choquette et al. 1971; Parker 1981; Huot and Beaulieu 1985) and, therefore, has not been actively sought during sampling of other herds. However, as sampling included manipulations of the liver to determine the prevalence and intensity of $T$. hydatigena, if an individual not from Quebec or Labrador was infected with F. magna, it would have been detected (B. Elkin, personal communication) given the size of this parasite (Pybus 2001). 


\section{Statistical analyses}

We divided analyses in three parts: i) the calculation of the overall prevalence and intensity, ii) the assessment of the factors explaining the prevalence and intensity of the studied parasites, and iii) comparisons among herds. We used R software version 2.15.3 (R Development Core Team 2013) for all analyses and the level of statistical significance was set at $\alpha<0.05$. We first calculated the overall prevalence and intensity for each parasite (means \pm SE) with all the data combined. Then, we used generalized linear mixed models (GLMM) to model the effects of different factors on the prevalence and intensity of parasites. We used models with a binomial distribution and a logit link function for the prevalence, and a Poisson distribution and a log link function for intensity. We used sex, age class, herd size, and season as fixed effects, and herd and year as random effects. Except for the intensity of $H$. tarandi and the prevalence of $F$. magna, we could not include interactions in our models because there was a quasi-complete separation of data points, indicating that an independent variable predicted a dependent variable almost perfectly in certain cases. We hence included interactions between sex and age class only in the models assessing the intensity of $H$. tarandi and the prevalence of $F$. magna. The package lme4 was used to estimate the parameters with the Laplace approximation (Bates et al. 2012). The package lsmeans was used to calculate the least-squared means and to make pairwise comparisons among the different groups of factors (e.g. among the three age classes) (Lenth 2013). $P$-values obtained with these a posteriori pairwise comparisons were adjusted using the Tukey method (Westfall and Young 1993). Finally, we compared herds in terms of prevalence and intensity of the studied parasites. Since there were gaps in the data, we used the results from the second part of the analyses to focus on certain groups of data. After determining which factor or combination of factors had a significant effect on the prevalence and the intensity of the 
studied parasites (e.g. we found an effect of sex on the prevalence), we focused the analyses on the data with sufficient sample size (e.g. we used only adults from the different studied herds to avoid a potential bias associated with age; Table 3). For all analyses, we used only groups of factors for which $n \geq 10$. Unequal sample sizes were due to different sampling effort among herds, seasons, and years. Herds that had a prevalence of $0 \%$ or $100 \%$ were excluded from herd comparisons because pairwise comparisons could not be calculated when they were included. For the giant liver flukes, we had sufficient data only from the Rivière-George herd to test for the effects of sex, age class, season, and herd size on the prevalence and intensity of flukes. However, the overall prevalence and intensity were calculated with combined data from both the Rivière-aux-Feuilles and the Rivière-George herds. We also compared the overall prevalence and intensity of giant liver flukes between these two herds. There were not enough data to conduct statistical analyses on the effects of sex, age class, season, and herd size on the intensity of nose bots, hydatid cysts, lungworms, and muscle cysts, as well as to conduct herd comparisons.

\section{Results}

\section{Hypoderma tarandi}

The overall prevalence was $97 \pm 1 \%$ (95\% C.I.: 96-98; see Appendix B for the overall prevalence and intensity of each parasites separated by herd, sex and age class), with no significant difference according to sex, age class, herd size (Table A1.A) and herd (Table A1.B). AkiaManiitsoq, Cape Bathurst and Kangerlussuaq-Sisimiut herds had a prevalence of $100 \%$. The overall intensity was $103 \pm 5$ warble larvae (95\% C.I.: $93-112)$, with a minimum of 1 , a median of 61 and a maximum of 1008 warble larvae. Intensity increased with age in males, but the opposite occurred in females (Figure 2; Tables A2.A, A3.A). The intensity of warble larvae in adult 
females differed among herds, specifically the Greenland Akia-Maniitsoq and KangerlussuaqSisimiut herds had exceptionally high counts (Figure 3A; Tables A2.B, A3.B).

\section{Cephenemyia trompe}

The overall prevalence of nose bot larvae was $22 \pm 2 \%$ (95\% C.I.: $18-27)$. Calves $(2 \pm 2 \%)$ had a lower prevalence than adults $(10 \pm 10 \%)(z=-2.74, p=0.02$; Tables A4.A, A5.A). The prevalence significantly differed among herds when comparing adults; Akia-Maniitsoq and KangerlussuaqSisimiut herds had particularly high counts (Figure 3B; Tables A4.B, A5.B) and no larvae were detected in the Bluenose East and Cape Bathurst herds.

\section{Taenia hydatigena}

The overall prevalence of $T$. hydatigena liver cysts was $19 \pm 1 \%$ (95\% C.I.: $17-22)$. Calves (5 $\pm 4 \%)$ had a lower prevalence than adults $(18 \pm 9 \%)(z=-2.90, p=0.01$; Tables A6.A, A7.A). Prevalence was higher when the herd size was high and decreasing $(7 \pm 5 \%)$ than when it was low and decreasing $(2 \pm 2 \%)(z=2.74, p=0.048$; Tables A6.A, A7.B $)$. When herd size was high and decreasing, the prevalence of liver cysts differed among herds for adults. The Teshekpuk herd had a particularly high prevalence whereas no cysts were reported from the Cape Bathurst herd (Figure 3C; Tables A6.B, A7.C). Data on intensity were only available from adults. The mean overall intensity across herds was $2.3 \pm 0.1$ liver cysts (95\% C.I.: 2.0-2.5), with a minimum of 1 , a median of 2 and a maximum of 11 liver cysts. There was no significant difference according to sex, herd size, and season (Tables A8.A, A9.A). The Teshekpuk herd (1.1 \pm 0.3$)$ had fewer liver cysts than the Bathurst $(2.7 \pm 0.2 ; z=2.98, p=0.02)$ and Beverly/Ahiak $(2.6 \pm 0.3 ; z=2.81, p=0.04)$ herds (Tables A8.B, A9.B). 


\section{Fascioloides magna}

Fascioloides magna was only present in the Rivière-George and Rivière-aux-Feuilles herds. The overall prevalence in these herds was $48 \pm 2 \%$ (95\% C.I.: $45-52, n=777$; data from Rivière-George

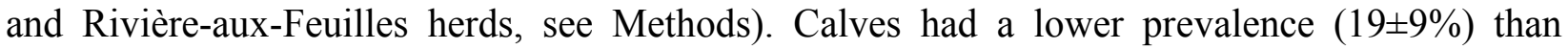
yearlings $(70 \pm 20 \%)(z=-3.16, p=0.005)$ and adults $(83 \pm 7 \%)(z=-6.56, p<0.001$; Tables A10.A, A11.A). Prevalence was highest during the herd peak and afterwards than at other times (Figure 4A; Tables A10.A, A11.B). Prevalence was lower during fall migration than during the rest of the year (Figure 4B; Tables A10.A, A11.C). During spring migration and when the herd size was near the peak, adults from the Rivière-George herd $(95 \pm 5 \%$; $n=20)$ had a higher prevalence of giant liver flukes than adults from the Rivière-aux-Feuilles herd $(40 \pm 10 \% ; n=25)(z=3.03$, $p=0.002$; Tables A10.B). For the intensity, there were data only available for adult females. The overall mean intensity was $12.6 \pm 0.9$ giant liver flukes (95\% C.I: $10.9-14.3, n=242)$, with a minimum of 1 , a median of 7 and a maximum of 80 giant liver flukes. In both herds, intensity was lower when the herd size was increasing than during the peak and afterwards (Figure 4C; Tables A12.A, A13.A). Intensity was higher during spring migration than during the rest of the year (Figure 4D; Tables A12.A, A13.B). During spring migration and when the herd size was near the peak, there was no significant difference in intensity between herds (Table A12.B).

\section{Echinococcus canadensis}

The overall prevalence was $4.8 \pm 0.6 \%$ (95\% C.I.: 3.6-6.0) with no significant difference

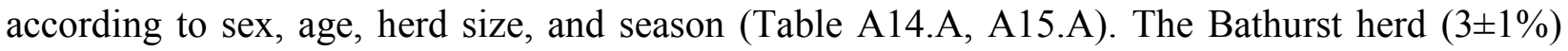

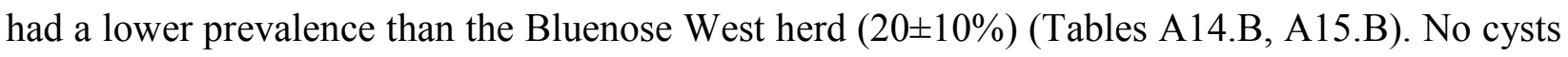
were reported from the Akia-Maniitsoq, Bluenose East, Cape Bathurst and KangerlussuaqSisimiut herds. 


\section{Dictyocaulus eckerti}

The overall prevalence for Dictyocaulus was $2.7 \pm 0.8 \%$ (95\% C.I.: 1.0-4.3). Prevalence was lower in late winter $(0.5 \pm 0.5 \%)$ than in late summer $(15 \pm 9 \%)(z=-2.94, p=0.009$; Tables A16.A, A17). During late winter, there was no significant difference according to herd (Table A16.B) and no Dictyocaulus was reported from the Beverly/Ahiak and Bathurst herds.

\section{Taenia krabbei}

The overall prevalence was $6.0 \pm 0.7 \%$ (95\% C.I.: 4.7-7.4) with no significant difference according to sex, age, herd size, and season (Table A18.A). The prevalence of muscle cysts was highest in the Western Arctic herd but did not differ significantly in the other herds (Figure 3D; Tables A18.B, A19). No T. krabbei cysts were reported from the Akia-Maniitsoq herd, but are known to occur (C. Cuyler, personal communication).

\section{Discussion}

This is the first study presenting the prevalence and intensity of infestation of seven of the main macroparasites of migratory caribou among twelve herds across North America and Greenland. This study was part of one of the most spatially and temporally intensive sampling effort for parasites of caribou across the circumpolar region. Our study is based on data that allowed us to test for individual traits (sex class and age), population characteristics (herd and herd size) and seasonal variability across a very large spatial scale. Our results revealed that sex, age, herd size, and season could partly explain the prevalence and intensity of some macroparasites of caribou and that caribou herds greatly differed in terms of parasitism. 


\section{Factors influencing prevalence and intensity}

$\operatorname{Sex}$

We found an effect of the sex of the host in interaction with age class on the intensity of $H$. tarandi larvae; intensity increased with age class for males while the opposite occurred in females. These results are consistent with observations from other studies showing that calves and juveniles generally had higher $H$. tarandi larvae infection intensities than adults, and males had a higher intensity than females (Helle 1980; Folstad et al. 1989; Thomas and Kiliaan 1990; Fauchald et al. 2007). Differences in the ability to mount an effective immune response to warble larvae could explain this phenomenon (Helle 1980). Indeed, in addition to the initial behavioral avoidance reactions to the presence of adult flies, caribou mount inflammatory responses to $H$. tarandi larvae when the first larval stages begin their sub-dermal migration. This migration occurs in autumn and is a vulnerable period in H. tarandi's life history (Helle 1980). The higher intensity of $H$. tarandi larvae in female calves that we observed could be explained by the lower and delayed response in the production of antibodies against the migrating larvae in calves because they have not yet acquired immunity against warble infection (Åsbakk et al. 2005). In adult males, the high levels of testosterone and corticosteroids produced during the rut may impede their acquired immune response against migrating first instar of $H$. tarandi larvae, possibly explaining the higher intensity of $H$. tarandi larvae in adult males (Folstad et al. 1989). Similarly and more generally, three meta-analyses reported higher mean prevalence and intensity of infection in males than in females for arthropods, helminths, and unicellular parasites in mammals (Poulin 1996; Schalk and Forbes 1997; Moore and Wilson 2002). 
Age class

We found an effect of age on the prevalence of $F$. magna, T. hydatigena, and $C$. trompe with adults having a higher prevalence than calves. For F. magna, the increase of prevalence with age may reflect a patchy spatial and temporal distribution of the parasite in the environment, a long prepatent period, and a long-lived parasite. Thus, older animals are more likely to have been exposed because they eat more than calves, and have done so over a much broader landscape and longer period of time. At the same time, because of the long prepatent period of the parasite, calves exposed late in their first summer may not have visible mature flukes in the liver until mid to late winter. Additionally, the adult parasites are long-lived, so increasing prevalence with age reflects cumulative infection over time (Pybus 2001). Indeed, mature giant liver flukes are known to live at least 5 years in white-tailed deer (Odocoileus virginianus Zimmermann, 1780) and may even live as long as their host (Foreyt et al. 1977; Lankester and Luttich 1988). The intensity of F. magna was similar in all age-classes which may reflect intraspecific competition among giant liver flukes, higher mortality of heavily infected hosts or resistance to reinfection of already infected hosts. For T. hydatigena, the increase in prevalence with age was consistent with the results from Thomas (1994) and may also reflect patchy exposure and cumulative infection over time. In contrast, for C. trompe, larvae leave the host every spring, hence there is no cumulative infection (Nilssen and Haugerud 1994) and our results of increased prevalence with age class may reflect an increased susceptibility to infection with age (Hudson and Dobson 1995). Adult female flies of $C$. trompe eject small groups of first instar larvae on the upper lip of caribou hosts and larvae migrate to the pharyngeal region where they develop (Anderson and Nilssen 1990). Flies could select adult hosts because they are larger and hence have larger pharyngeal regions, which could facilitate development of multiple larvae. Alternatively, heavily infected calves and yearlings could be more likely to die than heavily infected adults. 


\section{Herd size}

The prevalence and intensity of $F$. magna and the prevalence of $T$. hydatigena was associated with herd size. Data on the prevalence and intensity of F. magna and T. hydatigena have been collected since 1978 in the Rivière-George and the Rivière-aux-Feuilles herds while data on the prevalence of T. hydatigena have been collected since 1994 in the Beverly/Ahiak, Cape Bathurst, and Bluenose East herds. Prevalence and intensity of F. magna were higher during the herd peak and immediately afterwards than at other times, and prevalence of $T$. hydatigena was highest when the herd size was high and decreasing. These two parasites are environmentally transmitted (Table 2) and may be density dependent, thus prone to increased transmission at high host density (Arneberg et al. 1998; Patterson and Ruckstuhl 2013). In large, dense groups, parasite life cycles can be accelerated because more hosts are available for colonization and reproduction (Côté and Poulin 1995). Herd size may also affect host resistance to parasites if body condition and individual performance of hosts are reduced as a consequence of the herd size (Bonenfant et al. 2009). Good body condition may increase the ability of the host to inhibit parasitism (Coop and Kyriazakis 2001). A study conducted on caribou from the Rivière-George herd found that body condition was poorer when the herd size was nearing a peak and decreasing than when the herd size was low and increasing (Pachkowski et al. 2013). Thus, the highest prevalence and intensity of $F$. magna and T. hydatigena we found during the herd peak may be partly explained by the poor individual body condition at this time, but poor body condition could also be the result of a high parasite infection. However, because these two parasites have indirect transmission cycles and have to go through other hosts than caribou to complete their life cycle, the effect of the caribou herd size on the development of these parasites could be mitigated if the other hosts essential for the completion of the life cycle are absent or at very low densities. Similar observations of high prevalence and intensity during the decline phase of herd size could be 
explained by the retention of the parasites by these other hosts. For F. magna, aquatic snails of the family Lymnaeidae (Lamarck, 1799) are intermediate hosts and various stages of the parasite have been demonstrated to overwinter in snails (Pybus 2001). Hence, since the intermediate host populations are not affected by caribou abundance and $F$. magna is long-lived, high intensity of shedding may be happening in the environment even with declining caribou herd size. However, a delay in egg shedding may not take more than a year and could hence explain only partly why we found high prevalence and intensity years after the peak of the caribou population. For $T$. hydatigena, carnivores act as definitive hosts (Kutz et al. 2012) and eggs are long-lived in favourable environments, hence there could also be an ongoing shedding in the environment even when the caribou herd size is declining, especially if there is a time-lag between the caribou herd size and the population size of its predators.

\section{Season}

Season affected the prevalence and intensity of $F$. magna and the prevalence of $D$. eckerti, but not in the same manner. Prevalence of F. magna was lowest in the fall migration and the intensity of F. magna was highest in the spring migration. In white-tailed deer, mule deer (Odocoileus hemionus Rafinesque, 1817), and elk (Cervus elaphus L., 1758), F. magna has a prepatent period of approximately 6 months, which may explain why summer exposure to infective stages results in a peak of adult stages of the parasite in late winter and spring (Foreyt and Todd 1976; Foreyt 1996). The prevalence of $D$. eckerti was lower in late winter than in late summer, which is consistent with observed trends in muskoxen, caribou, and livestock where adult nematodes are short-lived and hypobiotic larvae (which would not be detected by our examinations) may remain in the lungs over-winter to mature the following spring (Kutz et al. 2012). The ability for $D$. eckerti to overwinter in the Arctic environment is not known, but egg and larval stages of other 
species of Dictyocaulus do not tend to persist in the environment under subzero temperatures (Ayalew et al. 1974).

\section{Herd comparisons}

Of the twelve studied herds, Greenland herds and both Quebec/Labrador herds were different from the rest of the herds in terms of the biodiversity, prevalence and intensity of the studied parasites.

\section{Akia-Maniitsoq and Kangerlussuaq-Sisimiut herds}

In Greenland, the prevalence of T. hydatigena and T. krabbei was low, while E. canadensis was not detected. These three parasites require carnivore definitive hosts, and although Arctic fox (Vulpes lagopus L., 1758) are present, wolves (Canis lupus L., 1758) are absent from the range of caribou in West Greenland and domestic dogs are uncommon, most likely preventing the establishment of E. canadensis (Rausch 2003). Arctic fox and polar bear (Ursus maritimus Phipps, 1774) can be definitive hosts of Taenia species and could hence be responsible for maintaining these parasites in Greenland at low prevalence (Kutz et al. 2012). Caribou from Greenland had a much greater abundance of $H$. tarandi and C. trompe. The short migration $(<200$ $\mathrm{km}$ ) of Greenland herds may be the principal factor explaining these high values (Cuyler et al. 2012), however, a relatively short host-parasite association caused by the recent introduction of these parasites to these historically isolated herds is also postulated as a reason for the high abundance. Longer migrations in North America could minimize reinfestation of $H$. tarandi and C. trompe by separating hosts from the areas where the larvae were dropped and adult flies eventually emerge (Thomas and Kiliaan 1990; Folstad et al. 1991). 


\section{Rivière-aux-Feuilles and Rivière-George herds}

The two caribou herds from Quebec and Labrador are the only ones with F. magna, and the Rivière-George herd had a higher prevalence than the Rivière-aux-Feuilles herd while intensity was not significantly different. The historical biogeography of both herds may be responsible for this peculiar parasite fauna. Fascioloides magna tends to have a patchy distribution across North America because it is thought that it cannot persist in areas without suitable snail intermediate hosts, as well as final hosts such as deer, elk and, caribou (Wobeser et al. 1985; Pybus 2001). The limited spread of F. magna to caribou of northeastern Canada remains unclear but is presumed to have occurred when the southern limits of the caribou range reached the southeastern United States (Yannic et al. 2014), where white-tailed deer and the now-extinct elk also ranged (Lankester and Luttich 1988). The Rivière-George and Rivière-aux-Feuilles herds are the only migratory caribou herds originating from populations whose range overlapped that of white-tailed deer and elk during the last glaciation (Yannic et al. 2014). Interestingly, prevalence was greater in the Rivière-George herd compared to the Rivière-aux-Feuilles herd and this difference could perhaps be explained by their distinct calving grounds and summer ranges (Couturier et al. 2004; Taillon et al. 2012). For F. magna, development in snail intermediate hosts depends on environmental conditions. Hence, there could be a difference in the summer environmental conditions between the summer ranges of the two herds that facilitate summer transmission of $F$. magna on the summer range of the Rivière-George herd but not on the summer range of the Rivière-aux-Feuilles herd. Further investigation on the differences in habitat, percent of wetlands, temperature, humidity, and vegetation type of these two summer ranges may reveal some insights into what may be driving the transmission of $F$. magna. 
The main limitation of this study was the presence of missing data due to differences in sampling effort according to herds, seasons and years. To reduce potential bias, standardized protocols were used during the sampling effort of 2007-2011, limiting the variability in data collection and allowing us to make comparisons of data from different sampling periods. However, sampling before 2007 was very similar to the standardized protocols of CARMA because they were largely inspired by the protocols used before 2007. Even if there is a potential bias due to differences in the probability of detection, this bias is reduced by the great similarity between protocols (Kutz et al. 2013a). Another limitation of this study is the small sample sizes used to assess the prevalence of some parasites in certain herds. Even if we did not include sample sizes of less than 10 culled caribou by herd, it is important to keep in mind that the results presented in this study do not represent the entire populations of migratory caribou. A strength of this study is the use of a database that spans several years and different seasons, age classes, and herd sizes across a very large spatial scale. The long-term research on the Rivière-aux-Feuilles and Rivière-George herds, combined with extensive collaboration and coordinated and standardized sampling of caribou during the International Polar year (Kutz et al. 2013a), were essential for these data to be gathered. Our study provides a substantial baseline of the macroparasites of caribou across broad geographical regions and for many herds, and establishes the foundation on which we can begin to evaluate the dynamics of parasitism in caribou over time. Further research should focus on long-term monitoring of parasites in caribou to increase our comprehension of the impacts of climate change on their life cycles and life history parameters. 


\section{Acknowledgments}

We thank the Government of Canada's International Polar Year Program for the financial support awarded to the CARMA network and the following agencies for in-kind support: ArcticNet, Université Laval, Caribou Ungava, University of Calgary, Government of Nunavut, Government of Yukon, University of Saskatchewan, Nunavik Research Center, Government of the Northwest Territories, Greenland Institute of Natural Resources and the Ministère des Forêts, de la Faune et des Parcs du Québec. A.-A. Simard was supported by ArcticNet and Caribou Ungava, which is mainly funded by the Natural Sciences and Engineering Research Council of Canada (NSERC), Hydro-Québec, Glencore Mine Raglan and the Fédération des pourvoiries du Québec and their partners. S. Kutz was supported by NSERC and Alberta Innovates. We thank J. Dau, L. Parrett, J. Invik and J. Wang for sampling and sample analyses and G. Yannic, G. Gauthier, J. Mainguy, and A. Stien for revision of an early version of the manuscript. 


\section{References}

Albon, S.D., Stien, A., Irvine, R.J., Langvatn, R., Ropstad, E., and Halvorsen, O. 2002. The role of parasites in the dynamics of a reindeer population. Proc. R. Soc. Lond. B Biol. Sci. 269(1500): $1625-1632$.

Anderson, J.R., and Nilssen, A.C. 1990. The method by which Cephenemyia trompe (Modeer) larvae invade reindeer (Rangifer tarandus). Rangifer, 10(3): 291-297.

Anderson, R.M., and May, R.M. 1978. Regulation and stability of host-parasite population interactions. I. Regulatory processes. J. Anim. Ecol. 47(1): 219-247.

Arneberg, P., Skorping, A., Grenfell, B., and Read, A.F. 1998. Host densities as determinants of abundance in parasite communities. Proc. R. Soc. Lond. B Biol. Sci. 265(1403): 1283-1289.

Åsbakk, K., Oksanen, A., Nieminen, M., Haugerud, R.E., and Nilssen, A.C. 2005. Dynamics of antibodies against hypodermin $\mathrm{C}$ in reindeer infested with the reindeer warble fly, Hypoderma tarandi. Vet. Parasitol. 129(3): 323-332.

Ayalew, L., Frechette, J., Malo, R., and Beauregard, C. 1974. Seasonal fluctuation and inhited development of populations of Dictyocaulus filaria in ewes and lambs. Can. J. Comp. Med. 38(4): 448 .

Bates, D., Maechler, M., and Bolker, B. 2012. lme4: Linear mixed-effects models using S4 classes. R package version 0.999999-0. URL < $\underline{\text { http://CRAN.R-project.org/package=lme4>. }}$.

Bonenfant, C., Gaillard, J.-M., Coulson, T., Festa-Bianchet, M., Loison, A., Garel, M., Loe, L.E., Blanchard, P., Pettorelli, N., Owen-Smith, N., Du Toit, J., and Duncan, P. 2009. Empirical 
evidence of density-dependence in populations of large herbivores. In Advances in Ecological Research. Edited by C. Hal. Academic Press. p. 313-357.

Brooks, D.R., and Hoberg, E.P. 2007. How will global climate change affect parasite-host assemblages? Trends Parasitol. 23(12): 571-574.

Catalano, S., Lejeune, M., Verocai, G.G., and Duignan, P.J. 2014. First report of Taenia arctos (Cestoda: Taeniidae) from grizzly (Ursus arctos horribilis) and black bears (Ursus americanus) in North America. Parasitol. Int. 63(2): 389-391.

Champagne, E., Tremblay, J.-P., and Côté, S.D. 2012. Tolerance of an expanding subarctic shrub, Betula glandulosa, to simulated caribou browsing. PloS One, 7(12): e51940.

Choquette, L.P.E., Gibson, G.G., and Simard, B. 1971. Fascioloides magna (Bassi, 1875) Ward, 1917 (Trematoda) in woodland caribou, Rangifer tarandus caribou (Gmelin), of northeastern Quebec, and its distribution in wild ungulates in Canada. Can. J. Zool. 49(2): 280-281.

Christe, P., Glaizot, O., Evanno, G., Bruyndonckx, N., Devevey, G., Yannic, G., Patthey, P., Maeder, A., Vogel, P., and Arlettaz, R. 2007. Host sex and ectoparasites choice: preference for, and higher survival on female hosts. J. Anim. Ecol. 76(4): 703-710.

Coop, R.L., and Kyriazakis, I. 2001. Influence of host nutrition on the development and consequences of nematode parasitism in ruminants. Trends Parasitol. 17(7): 325-330.

Côté, I.M., and Poulin, R. 1995. Parasitism and group size in social animals: a meta-analysis. Behav. Ecol. 6(2): 159-165. 
Couturier, S., Jean, D., Otto, R., and Rivard, S. 2004. Demography of the migratory tundra caribou (Rangifer tarandus) of the Nord-du-Québec Region and Labrador. Ministère des Ressources naturelles, de la Faune et des Parcs, Québec, Québec.

Cuyler, C., White, R.R., Lewis, K., Soulliere, C., Gunn, A., Russell, D.E., and Daniel, C. 2012. Are warbles and bots related to reproductive status in West Greenland caribou? Rangifer,(20): $243-258$.

Dale, B.W., Adams, L.G., and Bowyer, T.R. 1994. Functional response of wolves preying on barren-ground caribou in a multiple-prey ecosystem. J. Anim. Ecol. 63(3): 644-652.

Davidson, R., Simard, M., Kutz, S.J., Kapel, C.M.O., Hamnes, I.S., and Robertson, L.J. 2011. Arctic parasitology: why should we care? Trends Parasitol. 27(6): 239-245.

Davis, J.W., and Anderson, R.C. 1971. Parasitic diseases of wild mammals. Iowa State University Press.

Fauchald, P., Rødven, R., Bårdsen, B.-J., Langeland, K., Tveraa, T., Yoccoz, N.G., and Ims, R.A. 2007. Escaping parasitism in the selfish herd: age, size and density-dependent warble fly infestation in reindeer. Oikos, 116(3): 491-499.

Festa-Bianchet, M., Ray, J.C., Boutin, S., Côté, S.D., and Gunn, A. 2011. Conservation of caribou (Rangifer tarandus) in Canada: an uncertain future. Can. J. Zool. 89(5): 419-434.

Folstad, I., and Karter, A.J. 1992. Parasites, bright males, and the immunocompetence handicap. Am. Nat. 139(3): 603-622. 
Folstad, I., Nilssen, A.C., Halvorsen, O., and Andersen, J. 1989. Why do male reindeer (Rangifer tarandus) have higher abundance of second and third instar larvae of Hypoderma tarandi than females? Oikos, 55(1): 87-92.

Folstad, I., Nilssen, A.C., Halvorsen, O., and Andersen, J. 1991. Parasite avoidance: the cause of post-calving migrations in Rangifer? Can. J. Zool. 69(9): 2423-2429.

Foreyt, W.J. 1996. Mule deer (Odocoileus hemionus) and elk (Cervus elaphus) as experimental definitive hosts for Fascioloides magna. J. Wildl. Dis. 32(4): 603-606.

Foreyt, W.J., Samuel, W.M., and Todd, A.C. 1977. Fascioloides magna in white-tailed deer (Odocoileus virginianus): observations on the pairing tendency. J. Parasitol. 63(6): 1050-1052.

Foreyt, W.J., and Todd, A.C. 1976. Development of the large american liver fluke, Fascioloides magna, in white-tailed deer, cattle, and sheep. J. Parasitol. 62(1): 26-32.

Fréchette, J.-L. 1986. Guide pratique des principaux parasites et maladies de la faune terrestre et ailée du Québec. Faculté de Médecine Vétérinaire, Université de Montréal, Québec, SaintHyacinthe.

Gulland, F.M.D. 1992. The role of nematode parasites in Soay sheep (Ovis aries L.) mortality during a population crash. Parasitology, 105(3): 493-503.

Hamilton, W.D., and Zuk, M. 1982. Heritable true fitness and bright birds: a role for parasites? Science, 218(4570): 384-387. 
Harvell, C.D., Mitchell, C.E., Ward, J.R., Altizer, S., Dobson, A.P., Ostfeld, R.S., and Samuel, M.D. 2002. Climate warming and disease risks for terrestrial and marine biota. Science, 296(5576): 2158-2162.

Haukisalmi, V., Lavikainen, A., Laaksonen, S., and Meri, S. 2011. Taenia arctos n. sp.(Cestoda: Cyclophyllidea: Taeniidae) from its definitive (brown bear Ursus arctos Linnaeus) and intermediate (moose/elk Alces spp.) hosts. Syst. Parasitol. 80(3): 217-230.

Helle, T. 1980. Abundance of warble fly (Oedemagena tarandi) larvae in semi-domestic reindeer (Rangifer tarandus) in Finland. Reports from the Kevo Subarctic Research Station, 16: 1-6.

Hoar, B.M., Ruckstuhl, K., and Kutz, S. 2012. Development and availability of the free-living stages of Ostertagia gruehneri, an abomasal parasite of barrenground caribou (Rangifer tarandus groenlandicus), on the Canadian tundra. Parasitology, 139(8): 1093-1100.

Hoberg, E.P., Kutz, S.J., Galbreath, K.E., and Cook, J. 2003. Arctic biodiversity: from discovery to faunal baselines-revealing the history of a dynamic ecosystem. J. Parasitol. 89(Suppl): S84-S95.

Hoberg, E.P., Polley, L., Jenkins, E.J., Kutz, S.J., Veitch, A.M., and Elkin, B.T. 2008. Integrated approaches and empirical models for investigation of parasitic diseases in northern wildlife. Emerging Infect. Dis. 14(1): 10-17.

Höglund, J., Morrison, D., Divina, B., Wilhelmsson, E., and Mattsson, J. 2003. Phylogeny of Dictyocaulus (lungworms) from eight species of ruminants based on analyses of ribosomal RNA data. Parasitology, 127(02): 179-187. 
Hudson, P.J., and Dobson, A.P. 1995. Macroparasites: observed patterns in naturally fluctuating animal populations. In Ecology of infectious diseases in natural populations. Edited by B.T. Grenfell and A.P. Dobson. Cambridge University Press, Cambridge. p. 144-176.

Hudson, P.J., Dobson, A.P., and Newborn, D. 1998. Prevention of population cycles by parasite removal. Science, 282(5397): 2256-2258.

Hudson, P.J., Rizzoli, A., and Bryan, G. 2002. The ecology of wildlife diseases. Oxford University Press, Oxford.

Hummel, M., and Ray, J.C. 2008. Caribou and the north: a shared future. Dundurn Press Ltd, Toronto, Ontario.

Huot, J., and Beaulieu, M. 1985. Relationship between parasite infection levels and body fat reserves in George River caribou in spring and fall. In Proc. of the 2nd North American caribou workshop. Edited by T.C. Meredith and A.M. Martell. McGill Subarctic Research Paper, Val Morin, Québec. p. 317-327.

IPCC. 2013. Climate change 2013: The physical science basis. Contribution of working group I to the fifth assessment report of the Intergovernmental Panel on Climate Change. Cambridge University Press, United Kingdom and New York, NY, USA.

Irvine, R.J., Corbishley, H., Pilkington, J.G., and Albon, S.D. 2006. Low-level parasitic worm burdens may reduce body condition in free-ranging red deer (Cervus elaphus). Parasitology, 133(4): 465-475. 
Kutz, S., Ducrocq, J., Cuyler, C., Elkin, B., Gunn, A., Kolpashikov, L., Russell, D., and White, R.G. 2013a. Standardized monitoring of Rangifer health during International Polar Year. Rangifer, 33(21): 91-114.

Kutz, S., Ducrocq, J., Verocai, G., Hoar, B., Colwell, D., Beckmen, K., Polley, L., Elkin, B., and Hoberg, E. 2012. Parasites in ungulates of Arctic North America and Greenland: a view of contemporary diversity, ecology, and impact in a world under change. Adv. Parasitol. 79: 99-252.

Kutz, S.J., Checkley, S., Verocai, G.G., Dumond, M., Hoberg, E.P., Peacock, R., Wu, J.P., Orsel, K., Seegers, K., Warren, A.L., and Abrams, A. 2013b. Invasion, establishment, and range expansion of two parasitic nematodes in the Canadian Arctic. Global Change Biol. 19(11): $3254-3262$.

Kutz, S.J., Hoberg, E.P., Nagy, J., Polley, L., and Elkin, B. 2004. "Emerging” parasitic infections in Arctic ungulates. Integr. Comp. Biol. 44(2): 109-118.

Kutz, S.J., Hoberg, E.P., Polley, L., and Jenkins, E.J. 2005. Global warming is changing the dynamics of Arctic host-parasite systems. Proc. R. Soc. Lond. B Biol. Sci. 272(1581): $2571-2576$.

Kutz, S.J., Jenkins, E.J., Veitch, A.M., Ducrocq, J., Polley, L., Elkin, B., and Lair, S. 2009. The Arctic as a model for anticipating, preventing, and mitigating climate change impacts on hostparasite interactions. Vet. Parasitol. 163(3): 217-228.

Lankester, M.W., and Luttich, S. 1988. Fascioloides magna (Trematoda) in woodland caribou (Rangifer tarandus caribou) of the George River herd, Labrador. Can. J. Zool. 66(2): 475-479. 
Lavikainen, A., Laaksonen, S., Beckmen, K., Oksanen, A., Isomursu, M., and Meri, S. 2011. Molecular identification of Taenia spp. in wolves (Canis lupus), brown bears (Ursus arctos) and cervids from North Europe and Alaska. Parasitol. Int. 60(3): 289-295.

Lenth, R.V. 2013. 1smeans: Least-squares means. R package version 1.06-05. URL $<\underline{\text { http://CRAN.R-project.org/package }=\text { lsmeans }>}$.

May, R.M., and Anderson, R.M. 1978. Regulation and stability of host-parasite population interactions: II. Destabilizing processes. J. Anim. Ecol. 47(1): 249-267.

McCurdy, D.G., Shutler, D., Mullie, A., and Forbes, M.R. 1998. Sex-biased parasitism of avian hosts: relations to blood parasite taxon and mating system. Oikos, 82(2): 303-312.

Molnár, P.K., Dobson, A.P., and Kutz, S.J. 2013. Gimme shelter - the relative sensitivity of parasitic nematodes with direct and indirect life cycles to climate change. Global Change Biol. 19(11): 3291-3305.

Moore, S.L., and Wilson, K. 2002. Parasites as a viability cost of sexual selection in natural populations of mammals. Science, 297(5589): 2015-2018.

Morales-Montor, J., Chavarria, A., De León, M.A., Del Castillo, L.I., Escobedo, E.G., Sánchez, E.N., Vargas, J.A., Hernández-Flores, M., Romo-González, T., and Larralde, C. 2004. Host gender in parasitic infections of mammals: an evaluation of the female host supremacy paradigm. J. Parasitol. 90(3): 531-546.

Mowat, G., and Heard, D.C. 2006. Major components of grizzly bear diet across North America. Can. J. Zool. 84(3): 473-489. 
Musiani, M., Leonard, J.A., Cluff, H., Gates, C.C., Mariani, S., Paquet, P.C., Vilà, C., and Wayne, R.K. 2007. Differentiation of tundra/taiga and boreal coniferous forest wolves: genetics, coat colour and association with migratory caribou. Mol. Ecol. 16(19): 4149-4170.

Nilssen, A.C., and Haugerud, R.E. 1994. The timing and departure rate of larvae of the warble fly Hypoderma (= Oedemagena) tarandi (L.) and the nose bot fly Cephenemyia trompe (Modeer) (Diptera: Oestridae) from reindeer. Rangifer, 14(3): 113-122.

Olofsson, J., Oksanen, L., Callaghan, T., Hulme, P.E., Oksanen, T., and Suominen, O. 2009. Herbivores inhibit climate-driven shrub expansion on the tundra. Global Change Biol. 15(11): 2681-2693.

Pachkowski, M., Côté, S.D., and Festa-Bianchet, M. 2013. Spring-loaded reproduction: effects of body condition and population size on fertility in migratory caribou (Rangifer tarandus). Can. J. Zool. 91(7): 473-479.

Parker, G.R. 1981. Physical and reproductive characteristics of an expanding woodland caribou population (Rangifer tarandus caribou) in northern Labrador. Can. J. Zool. 59(10): 1929-1940.

Patterson, J.E., and Ruckstuhl, K.E. 2013. Parasite infection and host group size: a metaanalytical review. Parasitology, 140(7): 803-813.

Post, E., Forchhammer, M.C., Bret-Harte, M.S., Callaghan, T.V., Christensen, T.R., Elberling, B., Fox, A.D., Gilg, O., Hik, D.S., Høye, T.T., Ims, R.A., Jeppesen, E., Klein, D.R., Madsen, J., McGuire, A.D., Rysgaard, S., Schindler, D.E., Stirling, I., Tamstorf, M.P., Tyler, N.J.C., van der Wal, R., Welker, J., Wookey, P.A., Schmidt, N.M., and Aastrup, P. 2009. Ecological dynamics across the Arctic associated with recent climate change. Science, 325(5946): 1355-1358. 
Poulin, R. 1996. Sexual inequalities in helminth infections: a cost of being a male? Am. Nat. 147(2): 287-295.

Pybus, M.J. 2001. Liver flukes. In Parasitic diseases of wild mammals, 2nd edition. Edited by W.M. Samuel, M.J. Pybus and A.A. Kocan. Iowa State University Press, Ames, Iowa. p. 121-149.

Raundrup, K., Al-Sabi, M.N.S., and Kapel, C.M.O. 2012. First record of Taenia ovis krabbei muscle cysts in muskoxen from Greenland. Vet. Parasitol. 184(2): 356-358.

Rausch, R.L. 2003. Cystic echinococcosis in the Arctic and Sub-Arctic. Parasitology, 127(S1): S73-S86.

Russell, D.E., Kofinas, G., Gunn, A., White, R.G., and Kutz, S. 2013. CircumArctic Rangifer monitoring and assessment (CARMA) network-origins, goals, accomplishments and future. Rangifer, 33(21): 141-144.

Schalk, G., and Forbes, M.R. 1997. Male biases in parasitism of mammals: effects of study type, host age, and parasite taxon. Oikos, 78(1): 67-74.

Scott, M.E. 1988. The impact of infection and disease on animal populations: implications for conservation biology. Conserv. Biol. 2(1): 40-56.

Sharma, S., Couturier, S., and Côté, S.D. 2009. Impacts of climate change on the seasonal distribution of migratory caribou. Global Change Biol. 15(10): 2549-2562. 
Taillon, J., Brodeur, V., Festa-Bianchet, M., and Côté, S.D. 2012. Is mother condition related to offspring condition in migratory caribou (Rangifer tarandus) at calving and weaning? Can. J. Zool. 90(3): 393-402.

Team, R.D.C. 2013. R: A language and environment for statistical computing. Version 2.15.3. Edited by R.F.f.S. Computing, Vienna, Austria.

Thomas, D.C. 1994. Prevalence of Echinococcus granulosus and Taenia hydatigena in caribou in north-central Canada. Rangifer, 16(4): 331-336.

Thomas, D.C., and Kiliaan, H.P.L. 1990. Warble infestations in some Canadian caribou and their significance. Rangifer, 10(3): 409-417.

Vors, L.S., and Boyce, M.S. 2009. Global declines of caribou and reindeer. Global Change Biol. 15(11): 2626-2633.

Westfall, P.H., and Young, S.S. 1993. Resampling-based multiple testing: Examples and methods for p-value adjustment. John Wiley \& Sons.

Wilson, K., Bjørnstad, O.N., Dobson, A.P., Merler, S., Poglayen, G., Randolph, S.E., Read, A.F., and Skorping, A. 2001. Heterogeneities in macroparasite infections: patterns and processes. In The ecology of wildlife diseases. Edited by P.J. Hudson, A. Rizzoli, B.T. Grenfell, H. Heesterbeek and A.P. Dobson. Oxford University Press, Oxford. p. 6-44.

Wobeser, G., Gajadhar, A.A., and Hunt, H.M. 1985. Fascioloides magna: occurrence in Saskatchewan and distribution in Canada. Can. Vet. J. 26(8): 241-244. 
Yannic, G., Pellissier, L., Ortego, J., Lecomte, N., Couturier, S., Cuyler, C., Dussault, C., Hundertmark, K.J., Irvine, R.J., Jenkins, D.A., Kolpashikov, L., Mager, K., Musiani, M., Parker, K.L., Røed, K.H., Sipko, T., Pórisson, S.G., Weckworth, B.V., Guisan, A., Bernatchez, L., and Côté, S.D. 2014. Genetic diversity in caribou linked to past and future climate change. Nature Climate Change, 4(2): 132-137.

Zamin, T.J., and Grogan, P. 2013. Caribou exclusion during a population low increases deciduous and evergreen shrub species biomass and nitrogen pools in low Arctic tundra. J. Ecol. 101(3): 671-683.

Zuk, M. 1990. Reproductive strategies and disease susceptibility: an evolutionary viewpoint. Parasitology Today, 6(7): 231-233. 
Table 1: Sample sizes for sex (1=females, $2=$ males), age class $(1=$ calves, $2=$ yearlings, $3=$ adults $)$, herd size $(1=$ low and increasing, $2=$ high and increasing, $3=$ around the peak, $4=$ high and decreasing, $5=$ low and decreasing), and season $(1=$ winter, $2=$ late winter/early spring, $3=$ spring migration/calving grounds, 4=late summer, $5=$ fall migration) to assess which factors affect the prevalence - the percentage of infected individuals in the host population - and the intensity - the average number of parasites per infected host - of seven of the main macroparasites of caribou (Rangifer tarandus L., 1758). Data are from 2 or more herds for each parasite, except for Fascioloides magna (Bassi, 1875) that come only from the Rivière-George herd. The symbol « - » means that no data were collected for this category of sex, age class, herd size or season.

\begin{tabular}{|c|c|c|}
\hline \multirow{2}{*}{ Total } & Sex & Age class \\
\hline & 1 & 2 \\
\hline
\end{tabular}

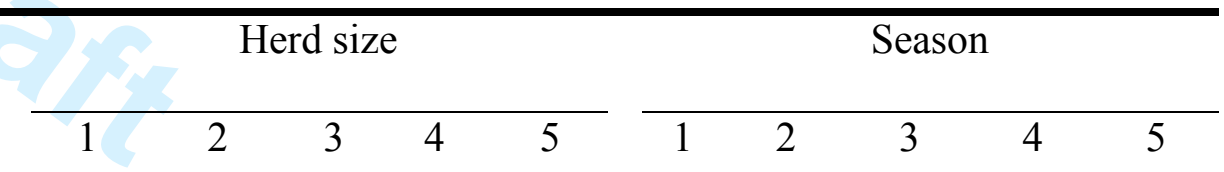

\begin{tabular}{|c|c|c|c|c|c|c|c|c|c|c|c|c|c|c|c|c|c|}
\hline Hypoderma & Prevalence & 650 & 528 & 122 & 63 & 72 & 515 & 156 & 176 & 25 & 225 & 68 & - & 650 & - & - & - \\
\hline tarandi & Intensity & 632 & 516 & 116 & 63 & 71 & 498 & 153 & 173 & 25 & 218 & 63 & - & 632 & - & - & - \\
\hline Cephenemyia & & & & & & & & & & & & & & & & & \\
\hline trompe & Prevalence & 335 & 281 & 54 & 24 & 11 & 300 & - & 77 & 25 & 166 & 67 & - & 335 & - & - & - \\
\hline Taenia & Prevalence & 958 & 790 & 168 & 132 & 21 & 805 & 16 & 122 & 108 & 364 & 348 & - & 358 & 184 & 145 & 271 \\
\hline hydatigena & Intensity & 171 & 141 & 30 & - & - & 171 & - & 11 & 22 & 77 & 61 & - & 80 & 39 & 34 & 18 \\
\hline
\end{tabular}




\begin{tabular}{|c|c|c|c|c|c|c|c|c|c|c|c|c|c|c|c|c|c|}
\hline Fascioloides & Prevalence & 542 & 467 & 75 & 85 & 19 & 438 & 11 & 289 & 20 & 27 & 195 & 13 & 151 & 142 & 60 & 176 \\
\hline magna & Intensity & 189 & 189 & - & - & - & 189 & - & 16 & 20 & 24 & 129 & - & 38 & 65 & 25 & 61 \\
\hline $\begin{array}{l}\text { Echinococcus } \\
\text { canadensis }\end{array}$ & Prevalence & 1197 & 969 & 228 & 166 & 37 & 994 & 20 & 364 & 108 & 344 & 361 & 11 & 471 & 214 & 177 & 324 \\
\hline $\begin{array}{l}\text { Dictyocaulus } \\
\text { eckerti }\end{array}$ & Prevalence & 374 & 288 & 86 & 29 & 13 & 332 & - & 104 & - & 145 & 125 & - & 232 & - & 115 & 27 \\
\hline $\begin{array}{l}\text { Taenia } \\
\text { krabbei }\end{array}$ & Prevalence & 1181 & 927 & 254 & 163 & 59 & 959 & - & 294 & 108 & 425 & 354 & 11 & 477 & 198 & 181 & 314 \\
\hline
\end{tabular}


Table 2: Description and life cycle of the seven main macroparasites of caribou (Rangifer tarandus L., 1758) used in our study (Davis and Anderson 1971; Fréchette 1986; Kutz et al. 2012).

\begin{tabular}{|c|c|c|c|c|c|c|c|}
\hline Name & Classification & $\begin{array}{l}\text { Length in } \\
\text { Rangifer } \\
\text { (cm) }\end{array}$ & Intermediate host(s) & $\begin{array}{l}\text { Position in the } \\
\text { intermediate host(s) }\end{array}$ & Definitive host(s) & $\begin{array}{l}\text { Position in the } \\
\text { definitive host(s) }\end{array}$ & $\begin{array}{l}\text { Immature form } \\
\text { (present in Rangifer) }\end{array}$ \\
\hline Hypoderma tarandi & $\begin{array}{l}\text { Order : Diptera } \\
\text { Family: Oestridae }\end{array}$ & $1-3$ & - & & Rangifer tarandus & Sub-dermal & - \\
\hline Cephenemyia trompe & $\begin{array}{l}\text { Order : Diptera } \\
\text { Family: Oestridae }\end{array}$ & $1-3$ & 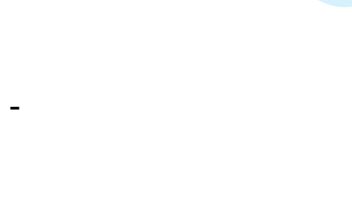 & - & Rangifer tarandus & $\begin{array}{l}\text { Pharyngeal } \\
\text { pockets and nasal } \\
\text { sinuses }\end{array}$ & 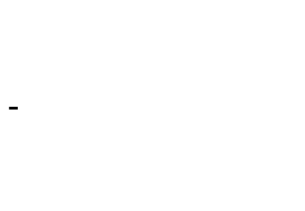 \\
\hline Taenia hydatigena & $\begin{array}{l}\text { Phylum : } \\
\text { Plathelminths }\end{array}$ & $0.1-5$ & $\begin{array}{l}\text { Alces americanus, } \\
\text { Cervus canadensis, } \\
\text { Odocoileus virginianus, } \\
\text { Ovis canadensis, } \\
\text { Odocoileus hemionus, } \\
\text { Rangifer tarandus, } \\
\text { Ovibos moschatus }\end{array}$ & $\begin{array}{l}\text { Liver, mesentery, } \\
\text { surface of } \\
\text { abdominal viscera }\end{array}$ & $\begin{array}{l}\text { Canis latrans, Canis lupus, } \\
\text { Lynx rufus, and other } \\
\text { carnivores }\end{array}$ & Small intestine & Cysticercus \\
\hline
\end{tabular}




\begin{tabular}{|c|c|c|c|c|c|c|c|}
\hline Fascioloides magna & $\begin{array}{l}\text { Phylum : } \\
\text { Plathelminths }\end{array}$ & $1-8$ & 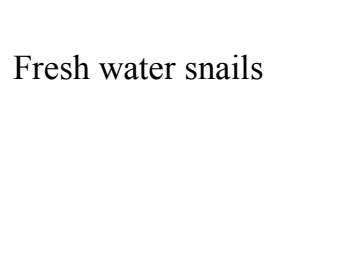 & Whole body & $\begin{array}{l}\text { virginianus, Odocoileus } \\
\text { hemionus, Rangifer } \\
\text { tarandus }\end{array}$ & Liver & - \\
\hline $\begin{array}{l}\text { Echinococcus } \\
\text { canadensis }\end{array}$ & $\begin{array}{l}\text { Phylum : } \\
\text { Plathelminths }\end{array}$ & $1-8$ & $\begin{array}{l}\text { Alces americanus, } \\
\text { Cervus canadensis, } \\
\text { Odocoileus virginianus, } \\
\text { Odocoileus hemionus, } \\
\text { Rangifer tarandus, } \\
\text { Ovibos moschatus }\end{array}$ & Lungs, liver & Canis latrans, Canis lupus & Small intestine & Hydatid cysts \\
\hline $\begin{array}{l}\text { Dictyocaulus } \\
\text { eckerti }\end{array}$ & $\begin{array}{l}\text { Phylum : } \\
\text { Nematoda }\end{array}$ & $1-12$ & 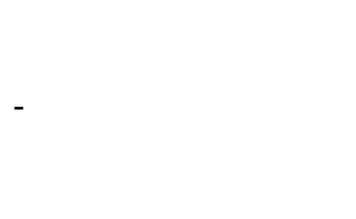 & - & $\begin{array}{l}\text { Alces americanus, } \\
\text { Odocoileus virginianus, } \\
\text { Rangifer tarandus }\end{array}$ & Lungs & - \\
\hline Taenia krabbei & $\begin{array}{l}\text { Phylum : } \\
\text { Plathelminths }\end{array}$ & $0.1-1$ & $\begin{array}{l}\text { Alces americanus, } \\
\text { Odocoileus hemionus, } \\
\text { Rangifer tarandus }\end{array}$ & Muscle, heart & $\begin{array}{l}\text { Canis latrans, Canis lupus, } \\
\text { Lynx rufus, Vulpeslagopus, } \\
\text { and other carnivores }\end{array}$ & Small intestine & Cysticercus \\
\hline
\end{tabular}


Table 3: Sample sizes used to compare twelve caribou (Rangifer tarandus L., 1758) herds in terms of prevalence - the percentage of infected individuals in the host population - and intensity - the average number of parasites per infected host - for seven of their main macroparasites. The symbol « - » means that no data were collected for this herd. Herds are presented according to their spatial distribution, from West to East.

\begin{tabular}{|c|c|c|c|c|c|c|c|c|c|c|c|c|c|}
\hline & & Western & Teshekpuk & Cape & Bluenose & Bluenose & & Beverly/ & Southampton & Rivière-aux- & Rivière- & Kangerlussuaq- & Akia- \\
\hline & & Arctic & & Bathurst & West & East & & Ahiak & Island & Feuilles & George & Sisimiut & Maniitsoq \\
\hline Hypoderma & Prevalence & - & - & 16 & - & 26 & 68 & 115 & 64 & - & 255 & 50 & 47 \\
\hline tarandi & Intensity & - & - & - & - & 22 & 50 & 87 & 16 & - & 168 & 40 & 41 \\
\hline $\begin{array}{l}\text { Cephenemyia } \\
\text { trompe }\end{array}$ & Prevalence & - & - & 15 & - & 26 & 57 & 113 & - & - & - & 40 & 41 \\
\hline Taenia & Prevalence & 16 & 14 & 15 & - & - & - & 88 & - & 98 & 26 & - & 40 \\
\hline hydatigena & Intensity & - & 11 & - & - & - & 50 & 36 & - & 37 & 21 & - & - \\
\hline Fascioloides & Prevalence & - & - & - & - & - & - & - & - & 25 & 20 & - & - \\
\hline magna & Intensity & - & - & - & - & - & - & - & - & 10 & 20 & - & - \\
\hline $\begin{array}{l}\text { Echinococcus } \\
\text { canadensis }\end{array}$ & Prevalence & 20 & 14 & 16 & 17 & 53 & 148 & 97 & - & 220 & 514 & 50 & 47 \\
\hline Dictyocaulus & Prevalence & - & - & - & - & 26 & 30 & 72 & - & - & - & 50 & 45 \\
\hline
\end{tabular}




\section{Canadian Journal of Zoology}

eckerti

Taenia

Prevalence

20

14

16

20

53

149

120 
Figure 1. Annual range of the twelve studied caribou herds (Rangifer tarandus L., 1758) in North America and Greenland. Sources: 1, 2, 3, 4, 5, 6, 7 annual ranges provided by CARMA (D. Russel, personal communication); 9, 10 annual ranges based on telemetry locations (100\% Minimum Convex Polygon); 8, 11, 12 annual ranges adapted from Hugo Ahlenius, UNEP/GRID-Arendal. Herds are presented according to their spatial distribution, from West to East.

Figure 2. Intensity - the average number of parasites per infected host - of warble larvae (Hypoderma tarandi L., 1758) according to age class in male (M) and female (F) migratory caribou (Rangifer tarandus L., 1758) during the late winter/early spring season (midFebruary to April). Different letters denote different means within sex and age classes (Table A3.A). Error bars represent mean \pm SE. Sample sizes are shown in parentheses.

Figure 3. A) Intensity - the average number of parasites per infected host - of warble larvae (Hypoderma tarandi L., 1758) in adult females during the late winter/early spring season (mid-February to April); B) Prevalence - the percentage of infected individuals in the host population - of nose bot larvae (Cephenemyia trompe Modeer, 1786) in adults during the late winter/early spring season; C) Prevalence of liver cysts (Taenia hydatigena Pallas, 1766) in adults when the herd size was high and decreasing; and D) Prevalence of muscle cysts (Taenia krabbei Moniez, 1879) in different herds of migratory caribou (Rangifer tarandus L., 1758). Herds are presented according to their spatial distribution, from West to East. Different letters denote different means (Tables A3.B, A5.B, A7.B, A19). Error bars represent mean \pm SE. Sample sizes are shown in parentheses. 
Figure 4. Prevalence - the percentage of infected individuals in the host population - of giant liver flukes (Fascioloides magna Bassi, 1875) according to A) herd size and B) season; mean intensity - the average number of parasites per infected host - of giant liver flukes according to C) herd size and D) season in caribou (Rangifer tarandus L., 1758) from the Rivière-George herd. The five seasons were defined considering the ecology of caribou and their parasites: winter (December to mid-February), late winter/early spring (mid-February to April), spring migration/calving grounds (May to July), late summer (August and September), and fall migration (October and November). Herd size was divided into five phases that accounted for both herd size and trend: low and increasing, high and increasing, around the peak, high and decreasing, and low and decreasing. For intensity, data were collected only from adult females and there was no data when the herd size was low and increasing. Different letters denote different means (Tables A11.B, A11.C, A13.A, A13.B). Error bars represent mean \pm SE. Sample sizes are shown in parentheses. 


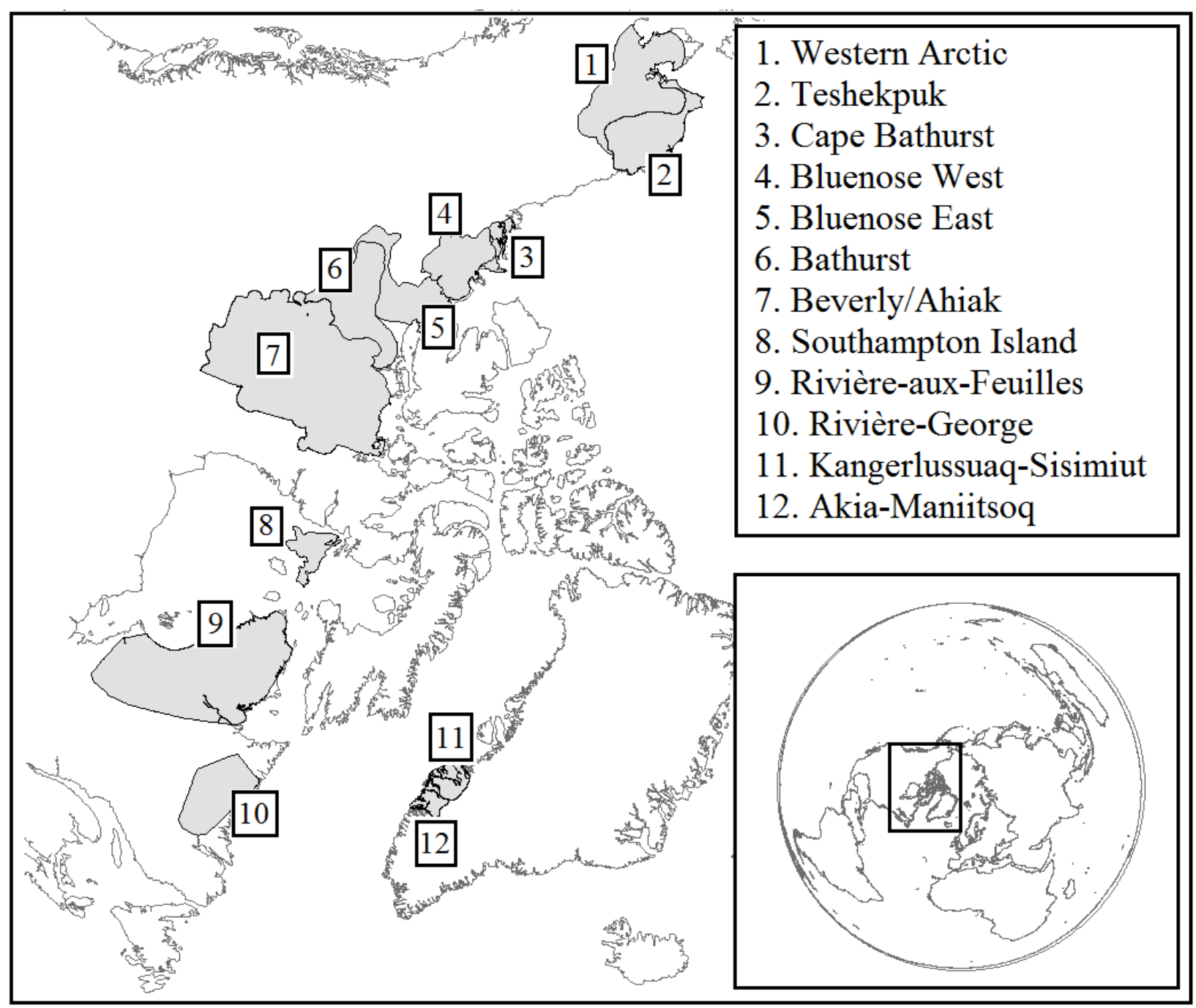



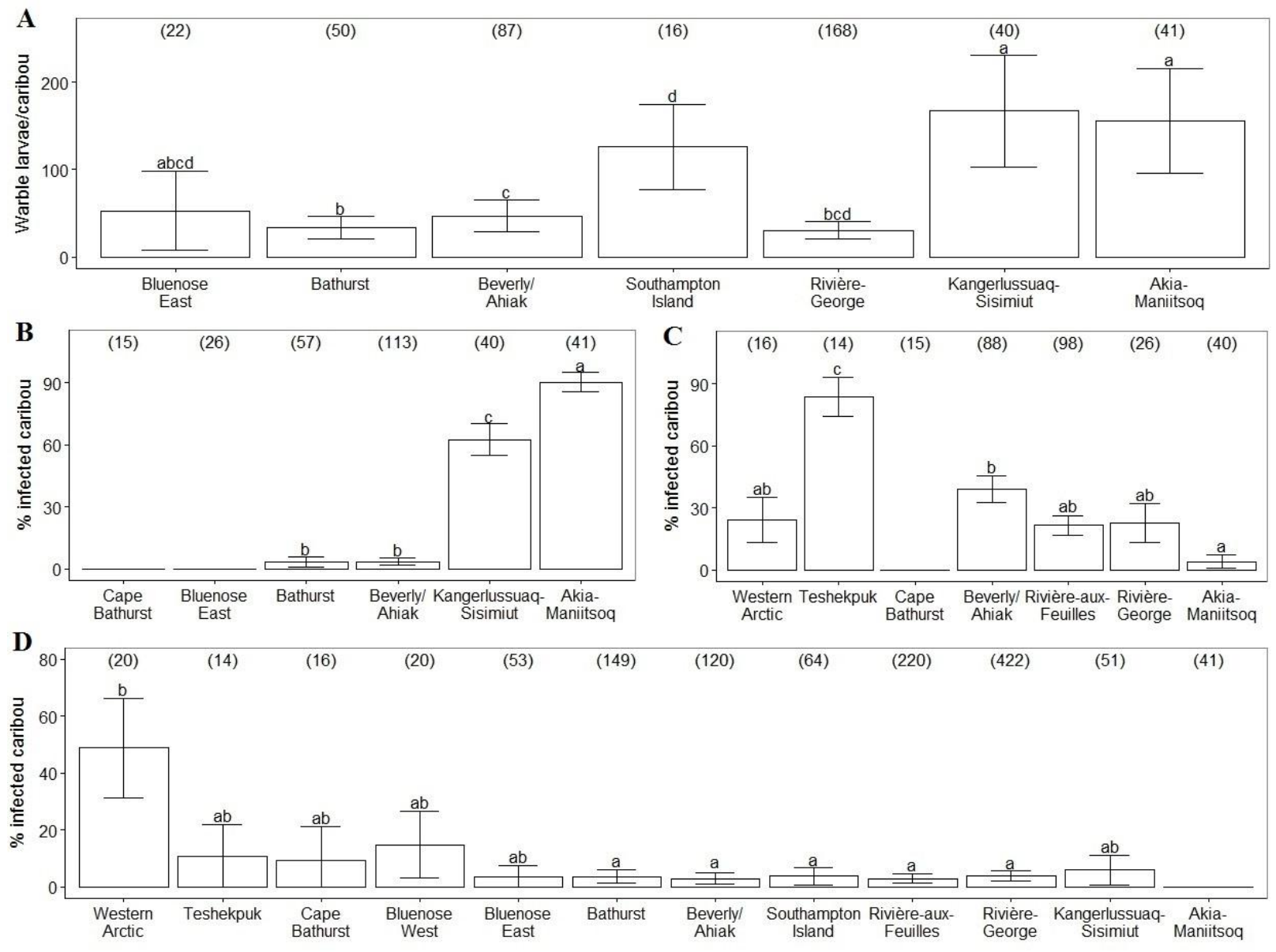

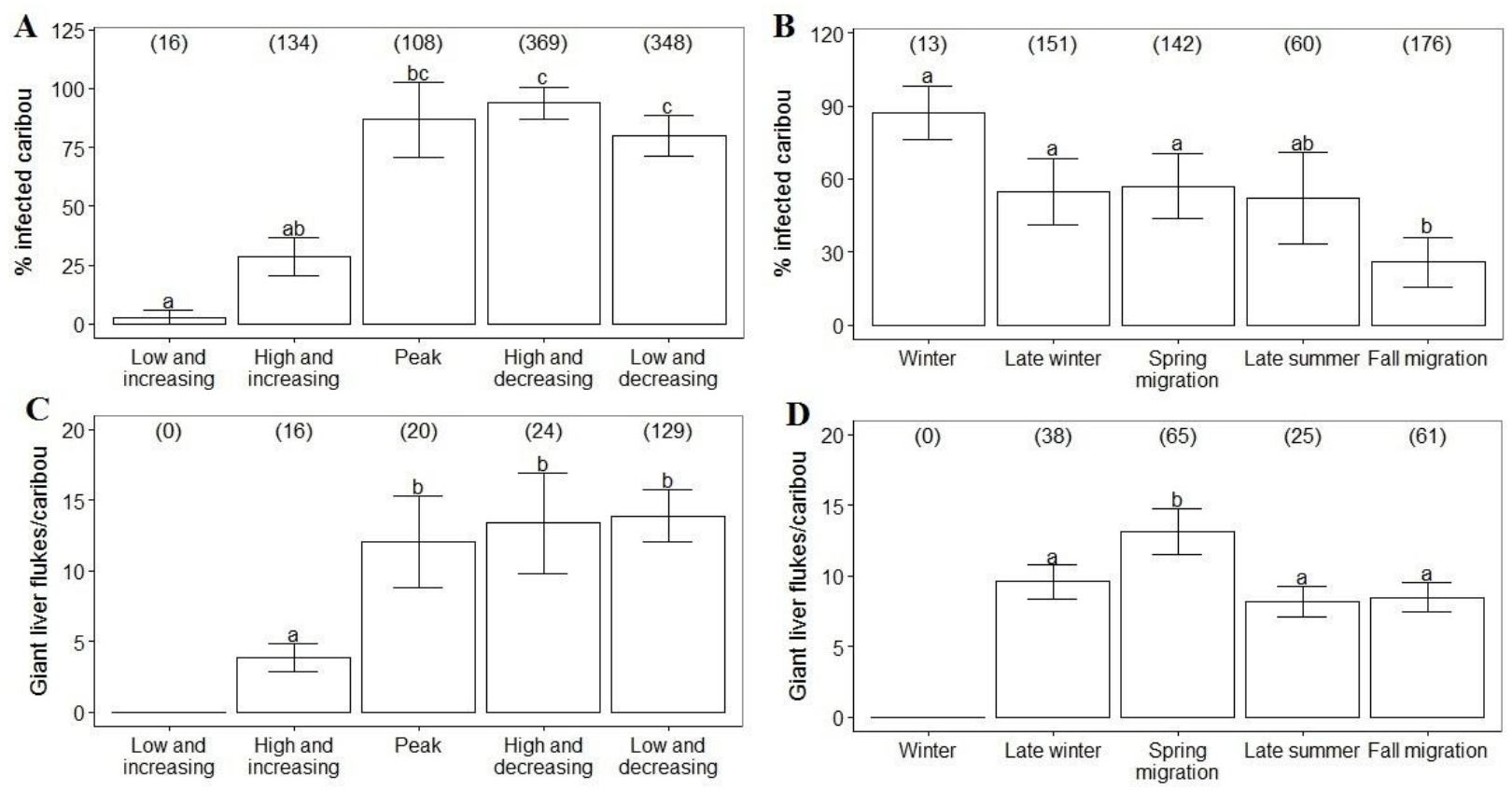